\title{
Collaborative Governance in Optimizing the Application of Electronic Health Care (E-Kes) in the Industrial Revolution 4.0 Era in Bengkulu City
}

\author{
Deni Triyanto ${ }^{1}$, Soehito Efendi ${ }^{2}$, Veny Puspita ${ }^{3}$ \\ \{dtriyanto992@gmail.com ${ }^{1}$, Soehito@unihaz.ac.id ${ }^{2}$, venypuspita2288@gmail.com ${ }^{3}$ \} \\ Program Studi Administrasi Publik Universitas Prof Dr Hazairin SH, Bengkulu Indonesia ${ }^{1}$ \\ Program Studi Administrasi Publik Universitas Prof Dr Hazairin SH, Bengkulu Indonesia ${ }^{2}$ \\ Program Studi Manajemen Universitas Prof Dr Hazairin SH, Bengkulu Indonesia ${ }^{3}$
}

\begin{abstract}
Bengkulu City is one of the regions in Bengkulu Province as an area that has the highest level of positive COVID-19, with these conditions should be able to change the mindsite of stakeholders in implementing E-Kes, stakeholders must be more responsive to emergency conditions by designing the E-Kes model. which is more effective and efficient. This study aims to analyze collaborative governance in the application of E-Kes in the era of the industrial revolution 4.0 in Bengkulu City. This research is a qualitative research, the informants in this study are stakeholders who have the capacity, namely the People's Representative Council (DPRD), the Provincial Health Office and the City of Bengkulu, Regional Hospitals, Puskesmas in Bengkulu City, Non-Governmental Organizations (NGOs). and Society. The results of this study indicate that the local government of Bengkulu City through the Bengkulu City Health Office has implemented E-Kes through an application issued by the Bengkulu Provincial Health Office. However, the results have not been maximally collaborative between the DPRD, Provincial Health Offices, Cities, Hospitals, Puskesmas, NGOs and the Community, so the implementation of E-Kes itself has not been optimal.
\end{abstract}

Keywords: Collaborative Governance, E-Kes, Bengkulu City.

\section{Introduction}

Provincial Health Office of Bengkulu until now doing repairs on the system kelolah based government information technology and incorporated into the program priorities of Bengkulu province, the Provincial Health Office of Bengkulu makes the application of e lektronik health (e-case), e-case made by the Health Department of Bengkulu province have implemented in 177 Puskesmas in Bengkulu Province. With the emergence of the e-kes application, it is hoped that it can help map human resources, infrastructure, health services from the health center level to the hospital in Bengkulu Province, which can be mapped properly starting from the availability of human resources at the Puskesmas, equipment infrastructure to types of diseases. By looking at the purpose and benefits of E-Kes that are managed by the Bengkulu Provincial Health Office, this study wants to examine collaboration in the application of E-Kes in Bengkulu Province[1]. 
Collaborative governance can be implemented by local governments in order to solve a public problem by collaborating with other parties involved in the problem solving process. In relation to Public Administration, collaborative governance is one of the new strategic models of government that involves various stakeholders or stakeholders simultaneously in a forum with government officials to make joint decisions that aim to resolve problems that cannot be faced alone by the government itself.[2]

Collaborative governance in the application of electronic health (e-kes) in Bengkulu City appears because the e-kes program is the result of the thought of the Bengkulu Provincial Health Office to be applied in various hospitals and Puskesmas, therefore collaboration between stakeholders is needed to optimize its implementation. In addition, the regional autonomy factor also greatly affects because each region has its own sectoral and territorial ego[3].

In the era of the industrial revolution 4.0, digitalization is needed to improve governance in order to increase the efficiency of costs, time and resources owned by each region. stated that traditionally, the public sector is a sector that is relatively less flexible in dealing with innovation than the business sector. The history and characteristics of public sector organizations that tend to be static, formal, and rigid have resulted in the public sector's reluctance to take advantage of innovation. On the other hand, the business sector is encouraged to continue to generate profits for its survival, while the public sector tends to be static because it feels that there is nothing to be pursued in order to maintain the survival of the organization.

Bengkulu City is the capital of Bengkulu Province so it is demanded to have better public services by increasing digital-based public service innovation, it's just that these changes towards digitalization are not easy because many think that change does not always bring good impact, so fears arise which really doesn't need to be a big problem for an organization.

[4], state that the system in the public sector is characterized by status-quo and and does not like change. In fact, not only in an institutional context, individual people rarely make inn ovation a part of their daily work. In general, individuals involved in the public sector only carry out their tusions as usual (business as usual). This condition may also be influenced by the absence of a reward and punishment system that is applied objectively in public sector organizations. This causes the individual not to be motivated to perform or to perform better.

The benefit of implementing the E-Kes program is to assist the government in mapping human resources, infrastructure, health services from the Puskesmas level to the hospital in Bengkulu Province. If the application of E-Kes in Bengkulu City can be applied optimally, the Bengkulu Provincial Health Office can analyze the availability of human resources at the Puskesmas for the next five years, Puskesmas facilities, medical equipment, types of diseases that exist in patients at Puskesmas, Hospitals and electronic-based health services that can be accessed by people anywhere. This has become the basis for the Bengkulu Provincial Health Office in making an E-Kes program to minimize accumulation of resources under the Bengkulu City District Health Office and other Regencies / Cities. 
Based on previous research, the collaboration process was carried out to solve budget problems and strengthen inter-related agencies in developing $e$-government innovations, the $e$ literacy process is carried out to increase community participation and human resource development by means of socialization to the community, training of trainers, and comparative studies [5], then according to the results of previous research that the success of collaborative governance is (1) the network has no role dominance (2) the actors are committed to achieving the same goals (3) build mutual trust (4) there are clear boundaries and rules (5) the authority, accountability, and responsibility of each actor according to their respective roles (6) delivery of information through direct socialization and mass media. Efforts to increase collaboration are carried out through strengthening cross-sector collaboration and communication, advocacy, optimizing the Regional Action Plan Strategy (SRAD), testimonials and improving human resources [6].

The collaborative governance process has not been optimally implemented, this is indicated by the obstacles that occur, namely there is no communication forum, there is still sectoral ego, limited resources, and less than optimal private involvement [7]. In line with previous research and the importance of the benefits of collabotrative governance in the application of E-Kes in Bengkulu City, the author uses the theory according to the Collaborative Governance Model according to Ansell and Gash consisting of several stages, namely : Starting Condition, Leadership facilitative, Design istitusional (Institutional Design), and process Collaboration ( Collaborative process ).

\section{Methodology}

The research method used is a qualitative research method, this type of research is descriptive [8]. The focus of this research is on Collaborative Governance in the implementation of E-Kes in Bengkulu City. The focus of this research is Bengkulu City .

The main instrument in this study is the researcher himself and is supported by supporting instruments such as interview guides, documentation studies. The benefits of supporting instruments are to complement the weaknesses of the researcher's own instruments [9].

Secondary data used is document or literature study. Secondary sources are defined as historical sources, biographies, encyclopedias and other reference books, essays, books and articles which are reported or interpreted in written works by other or second parties[10]. The unit of analysis of this research that the Bengkulu Provincial Health Office, Health Office of the city of Bengkulu and Inpatient Health Center Bengkulu City. The informants of this research were the Secretary of the Bengkulu Provincial Office, the City and the authorized officials, policy implementers, the Head of the Puskesmas, the P uskesmas operator. 


\section{Finding and Discussion}

\subsection{Collaborative Governance in Optimizing the Application of Electronic Health Care (E-Kes) in the Industrial Revolution 4.0 Era in Bengkulu City}

Collaborative governance can be implemented by local governments aimed at solving governance problems, by collaborating with stakeholders regarding these problems. With regard to Public Administration, collaborative governance is a new strategic model of government that involves various stakeholders or stakeholders simultaneously in a forum with government officials to make joint decisions that aim to resolve problems that cannot be faced alone by the government itself [11].

The success or failure of collaborative governance according to the Collaborative Governance Model according to Ansell and Gash consists of several stages, namely : Starting Condition (Initial Conditions), Facilitative Leadership , Institutional Design, and Collaborative Process.

\subsection{Starting Condition}

The initial conditions of collaboration in Optimizing the Application of Electronic Health Care (E-Kes) in the Industrial Revolution 4.0 Era in Bengkulu City, it can be concluded that there are differences in resources and authority owned by stakeholders, because there are still visible differences in perceptions regarding the application of e-kes in Bengkulu City. The difference in perceptions between the Bengkulu Provincial Health Office and the Bengkulu Health Office is very striking because the Bengkulu City Health Office wants to keep using other applications made by the Bengkulu City Health Office compared to implementing the ekes application, the Bengkulu Provincial Health Office has previously carried out socialization and training on application health electronics in Bengkulu City, where in the era of the 4.0 industrial revolution it is highly expected that all government agencies apply digital governance for time and cost efficiency, the regulation of electronic government implementation in Bengkulu City is still based on Governor Regulation Number 17 of 2018 concerning the $e$ government master plan [1]

\subsection{Facilitative Leadership}

Leadership is leadership is the ability to influence the behavior of others in certain situations so that they are willing to work together to achieve the goals set.[12]. Leadership facilitative on collaboration in the optimization of the application of electronic kesehetan (E$\mathrm{Kes}$ ) in the era of industrial revolution $4.0 \mathrm{~d}$ i Bengkulu City has not run optimally dikarena assistance for the implementation of e-cases at community health centers (Puskesmas) only conducted the situational and if diperlukkan only, it also adversely affects the ability of e-case oprator Inpatient Health Center Bengkulu city because communication involves stakeholders only in the form of what SSAP. Lack of role of stakeholders in the duties and functions so penaraan e-cases not running optimally, Supervision collaboration activities carried out by each - each stakeholder internally and carried out by the Head of D carbuncle or Head of the Institution, the supervision is not optimal because it does not involve people in Bengkulu. 


\subsection{Institutional Design}

Institutional design collaboration Application of Electronic Kesehetan (E-Kes) In the era of the Industrial Revolution 4.0 In Bengkulu City refers to the Governor Regulation No. 17 Year 2018 on a master plan of e-government, $\mathrm{m}$ asterplan $e$ - $g$ overnment is the policy direction and strategies that can be general guidelines in the context of planning and executing an associated with $\mathrm{p}$ Developing $e$ - $g$ overnment making it more systematic, purposeful, continuous in order to support the work of local government functions towards the effectiveness of public services as well as services between government agencies . For clarity, the standard operating procedures of each stakeholder are clear enough to be used in carrying out their main tasks and functions related to the implementation of e-kes.

\subsection{Collaborative Process}

Process kolaboratif on kolaborasi $\mathrm{p}$ Application of elektronik kesehetan (E-Kes) $\mathrm{p}$ No e ra $\mathrm{r}$ evolution i ndustri $4.0 \mathrm{~d}$ i Bengkulu City can be concluded that the implementation of the collaborative process is not going well because of the lack of supporting an variable dialogue face to face related with formal and informal communication, resulting in a lack of information between the stakeholders . Communication is more often done informally through group whatsapp, and communication is done situational and each year is not fixed $\mathrm{p}$ elaksanaannya $\mathrm{k}$ epercayaan and $\mathrm{k}$ commitment of each stakeholder is still lacking . there is no regulation on cooperation between regions or stakeholders, so that it has an impact on the low coordination between the Bengkulu City Health Office and the Bengku Provincial Office in implementing e-kes of Bengkulu City, there is an inequality in the conditions of each region in responding to the application of e-kes of Bengkulu City and unclear position budget for e-kes e-kes of Bengkulu City.

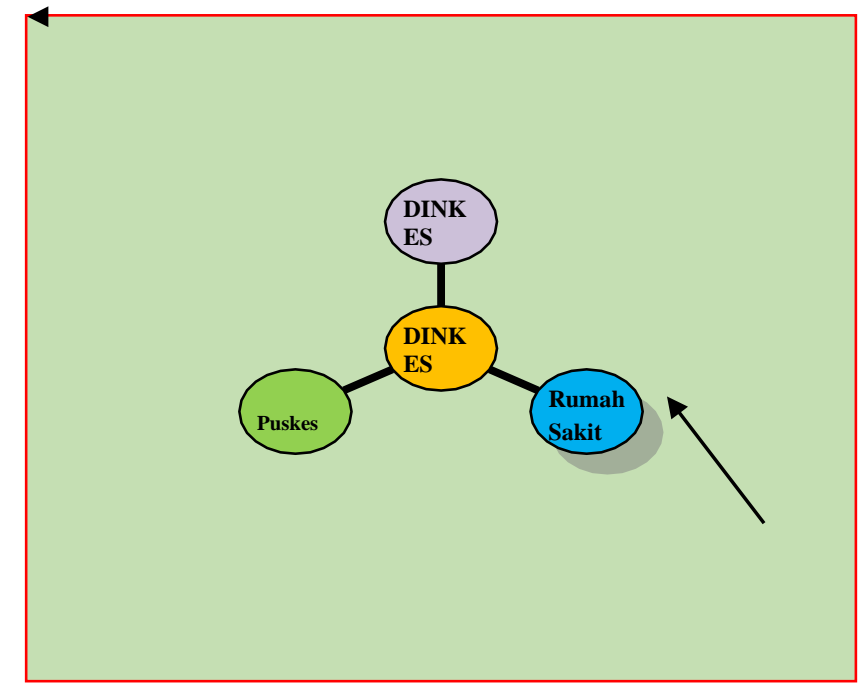

Fig. 1.The Process of Sharing the Authority for the Application of e-Kes in Bengkulu City (Source: analysis of the 2020 Research results) 


\section{Conclusion}

From this research, it can be concluded that there are several things, namely: collaborative governance in the implementation of e-kes of Bengkulu City has not been maximized because of the low inter-regional cooperation network with related agencies, namely: DPRD, Health Service, Private, Community and related local governments, namely the Bengkulu Provincial Government. This is due to the absence of regulations on cooperation between regions or stakeholders, resulting in low coordination between the Bengkulu City Health Office and the Bengku lu Provincial Office in implementing e-kes of Bengkulu City, there is an inequality in the conditions of each region in responding to City e-cases. Bengkulu and the unclear position of the budget in the e-kes implementation of Bengkulu City.

\section{References}

[1] D. Triyanto and S. Efendi, "Analisis Penerapan Elektronik Kesehatan ( E-Kes ) di Puskesmas Rawat Inap Kota Bengkulu," vol. 9, no. 2, pp. 158-165, 2019, doi: http://dx.doi.org/10.31289/jap.v9i2.2901.

[2] Harmiati, Alexsander, D. Triyanto, M. Maya, and F. Riastuti, "ANALISIS PEMETAAN COLLABORATIVE GOVERNANCE DALAM PROGRAM Keluarga BerenCANA DI KOTA BENGKUlU," Mimb. J. Penelit. Sos. dan Polit., vol. 9, no. 1, 2020.

[3] M. Muqorrobin, "Proses Collaborative Governance dalam Bidang Kesehatan (Studi Deskriptif Pelaksanaan Kolaborasi Pengendalian Penyakit TB-HIV di Kabupaten Blitar," Kebijak. dan Manaj. Publik, vol. 4, no. 1, pp. 1-9, 2016.

[4] W. Witanti and G. Abdillah, "Sistem Informasi Pelayanan Kesehatan Sebagai Upaya Peningkatan Kinerja E-Government," no. November, 2018.

[5] M. Rozikin, W. Hesty, and S. Sulikah, "Kolaborasi dan E-Literacy: Kunci Keberhasilan Inovasi E-Government Pemerintah Daerah,” J. Borneo Adm., vol. 16, no. 1, pp. 61-80, 2020, doi: $10.24258 /$ jba.v16i1.603.

[6] L. Rahmawati and U. Dewi, "DINAMIKA COLLABORATIVE GOVERNANCE DALAM PENANGGULANGAN HIV DAN AIDS DI KOTA YOGYAKARTA," Adinegara, vol. 7, no. 2, pp. 203-216, 2018.

[7] D. Arianti and L. Satlita, "COLLABORATIVE GOVERNANCE DALAM PENGEMBANGAN KONSERVASI MANGROVE BAROS DI DESA TIRTOHARGO KECAMATAN KRETEK KABUPATEN BANTUL,” pp. 809-827, 2018.

[8] L. J. Moleong, metodologi penelitian kualitatif, Jakarta. ROSDA, 2011.

[9] J. W. Creswell, Research Design Qualitative, Quantitative, and Mixed Methods Approaches, Second Edi. London: University of Nebraska, 2018.

[10] J. W. Creswell, Research Design (Pendekatan Kualitatif, Kuantitatif, dan Mixed). Yogyakarta: Pustaka Pelajar., 2014.

[11] R. A. Febrian, "COLLABORATIVE GOVERNANCE DALAM PEMBANGUNAN KAWASAN PERDESAAN ( Tinjauan Konsep dan Regulasi )," WEDANA $J$. Pemerintahan, Polit. dan Birokrasi, vol. II, pp. 200-208, 2016.

[12] C. B. M. Nazlen, Kepemimpinan Pendidikan. 1-3, 2019. 